\title{
The restoration in the torrent Los Meses, Spain
}

\author{
J. L. García ${ }^{1}$, J. A. Cuchí ${ }^{2} \&$ R. Gairín ${ }^{1}$ \\ ${ }^{I}$ Department of Forestry Engineering, Hydraulic \& Hydrology Lab, \\ University Polythecnic of Madrid (U.P.M.), Spain \\ ${ }^{2}$ Polytechnic School of Huesca, University of Zaragoz, Spain
}

\begin{abstract}
Canfranc-village is situated on the alluvial cone of a torrent called 'Los Meses'. The village lies on the highway to France (N-330), along the right bank of the river Aragon, into which the torrent discharges. The progressive deforestation of the basin of this ravine for the purposes of agriculture, pastures and firewood, a circumstance common in many Pyrenean valleys, caused the torrent to become dangerous for the village during the 18th and 19th centuries. In fact, it was so dangerous that the local people were forced to work to build and fortify a defensive stone wall every time there was a flood. The wall once stood at a height of more than $5 \mathrm{~m}$, and a width of almost $4 \mathrm{~m}$. Finally, at the beginning of the 20th century, the Spanish engineers Ayerbe and Azpeitia took charge of the stream control works. The stream control works carried out were cause for admiration in the profession. There is indeed considerable bibliography preserved from that time in which the dangers of the torrent and the magnificent works that inactivated it are described. Nevertheless, inexplicably no administration has preserved any trace of the original document for those stream control works. The succession of check-dams, perfectly integrated into the profile of the bed and the landscape, not only causes a compensation slope, but makes each dike section get wider, and it also acts like an area of lamination on the avenue. Because of that, and because of the large size of the materials and the soil and moss that grow on them, the values of the solid flows do not seem very credible. It is very unlikely that these materials will move, but even if they did, it would be less probable that they could be found in the outlet of the basin. Numerous structures, as well as profuse vegetation, would stop them. It is easy to observe that in some check-dams the flow digresses over deposited materials, like in a small alluvial cone.
\end{abstract}

Keywords: torrential hydraulics, debris flow, restoration works. 


\section{Introduction}

\subsection{The stream control works of Benito Ayerbe}

'Los Mese' is a small torrent, with a basin of 163.55 ha, but with steep slopes: its highest point is $1,991 \mathrm{~m}$, while the altitude at the outlet section is $1,090 \mathrm{~m}$., for a length of $2 \mathrm{~km}$. Its discharge into the River Aragon (figure 1), after crossing the alluvial cone, takes place at $1,015 \mathrm{~m}$.

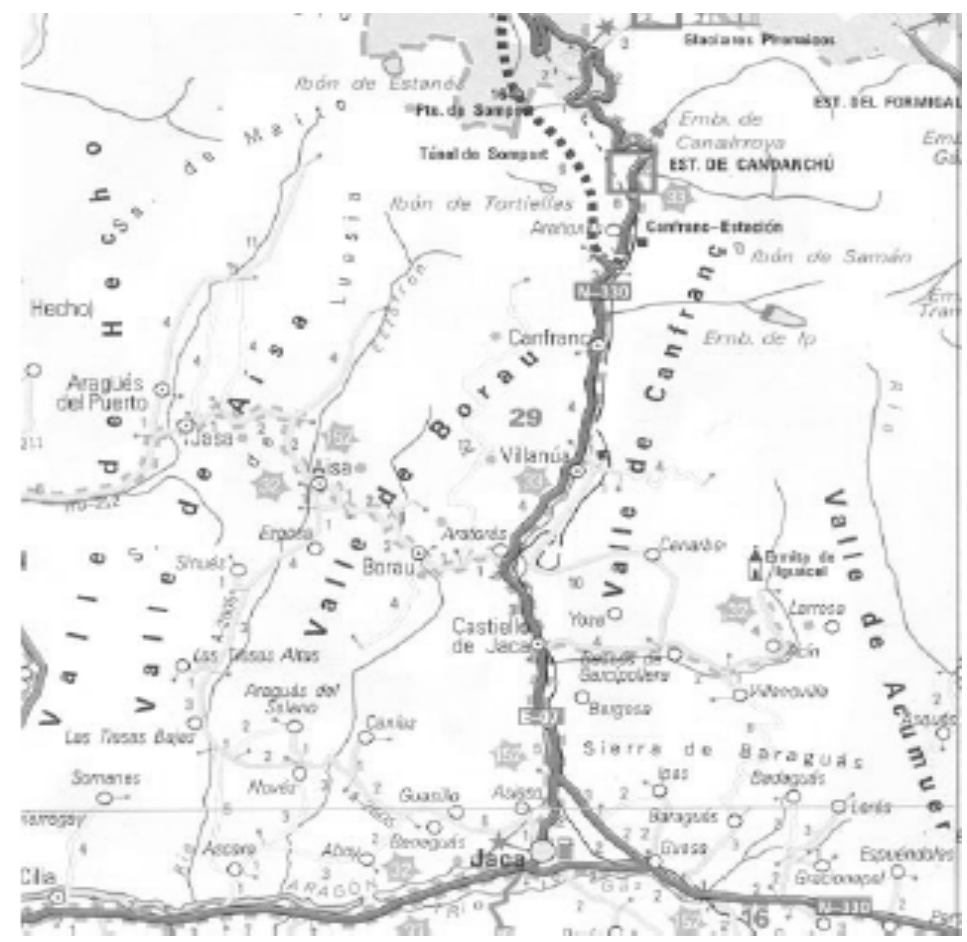

Figure 1: Valley and village.

The average gradient of the riverbed, before the works, was $30 \%$, and that of the watershed was $52 \%$. The torrent (figure 2), in the high area, has two branches of similar length that join at approximately $1370 \mathrm{~m}$., to descend together until they reach the River Aragon (figures $3 \& 4$ ).

The common area was called "the lower reach" (including the ravine). The area with two branches was called the "middle reach"; and the high part of the basin, without a riverbed, "the upper reach". At the time of the works, the basin was almost completely deforested. 


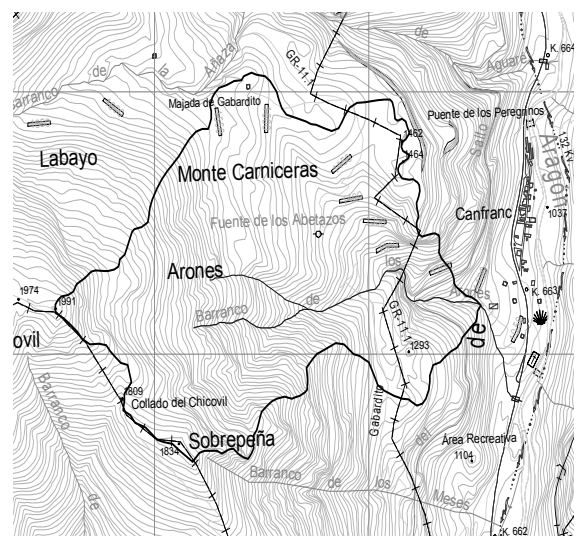

Figure 2: Watershed of the torrent Los Meses.

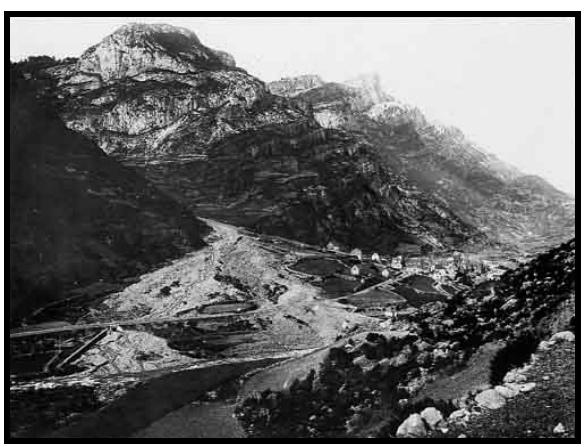

Figure 3: The torrent before the restoration works.

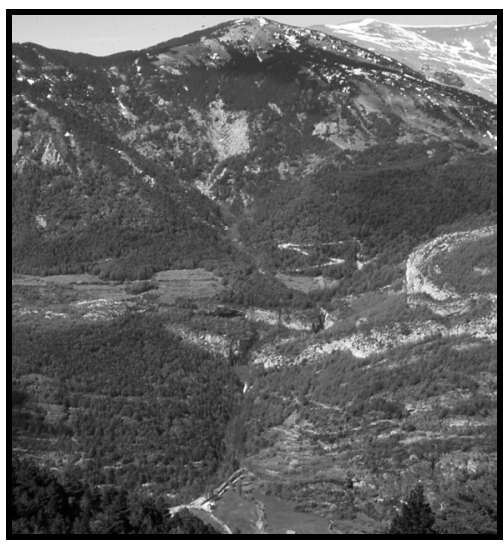

Figure 4: View of the current watershed. 


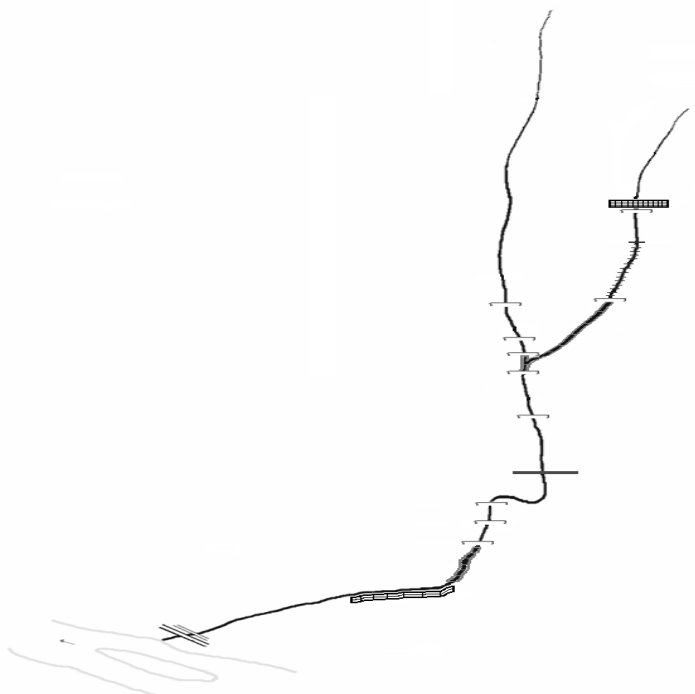

Figure 5: Framework of works in the torrent.

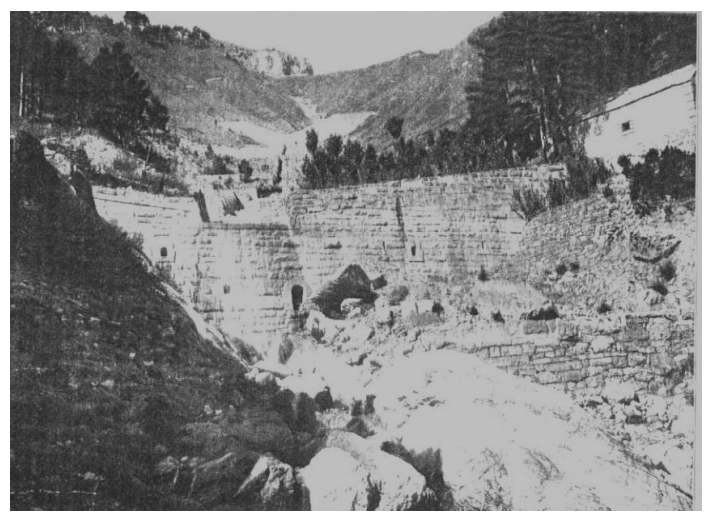

Figure 6: The check-dam in control section.

The following stream control works (figure 5) were carried out:

- In the lower reach a hydraulic channelling of reaches subject to erosion and four check-dams were done. The channelling, $95 \mathrm{~m}$ long and $6.5 \mathrm{~m}$ wide, consisted of 11 steps and included 11 grills ranging from $1.5 \mathrm{~m}$ to $2 \mathrm{~m}$ in height, together with longitudinal walls. The channelling begins where a wall built by the locals ends, and it is followed by three hydraulic masonry check-dams, of heights between $5.5 \mathrm{~m}$ and $9 \mathrm{~m}$ before the ravine. The fourth dike of this reach, of dry masonry $6 \mathrm{~m}$ in height, was situated after the ravine (following the torrent upstream). This whole reach was reforested with Pinus sylvestris, and the alluvial cone and lower riverbed were reforested with broadleaf trees. 


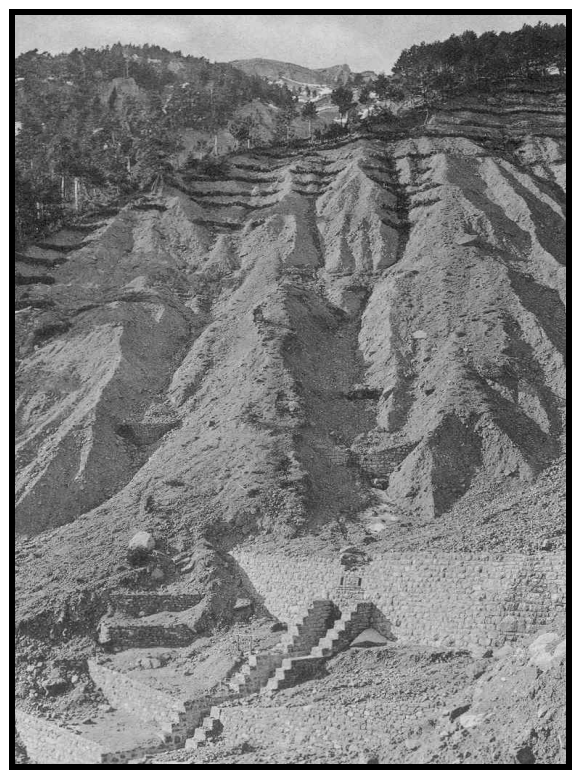

Figure 7: Final check-dam with the canalization and lateral gabions and fascines.

- In the middle reach the two branches were identified. A dike was built at the beginning of the reach, before the bifurcation (figure 6). On the left branch a $179 \mathrm{~m}$ long channelling was built, with 32 steps, of variable width ( $3 \mathrm{~m}$ in the high part, $5 \mathrm{~m}$ in the low part), and also of variable height. Five traverse check-dams were built across this channelling. Along the channelling 52 traverse fins (figure 7) were built going from the longitudinal walls and embedded into the other side of the mountain side, in order to give it support $[1,2]$.

- On the right branch, a short channel was built, barely $11 \mathrm{~m}$ long, followed by three check-dams. The first two check-dams were of hydraulic masonry (4.5m and $8 \mathrm{~m}$ high, $33 \mathrm{~m}$ apart) and the last one was of dry masonry $(75 \mathrm{~m}$ upstream, $8 \mathrm{~m}$ high, figure 8 ). This whole reach was reforested with $\mathrm{P}$. sylvestris. No work was undertaken in the higher reach. It was reforested with P. uncinata [3].

- In the left branch of 'Los Meses' torrent, above the dike that closes the channelling, there is a succession of 22 walls or check-dams of gabion masonry, using a construction technique different to what is used nowadays to build gabions. They are more like dry masonry walls that have then been covered with a metallic mesh.

- There is no contemporary record referring to the construction of these gabions, which would suggest that they were added after the original project.

- However, it could not have been much later, because there are no local records of works carried out in the torrent since the 1940s. Therefore, it is 
not known when these works date from, who carried them out or why. However, specialized articles published in 1924 and 1925 praised the original works for working quite efficiently.

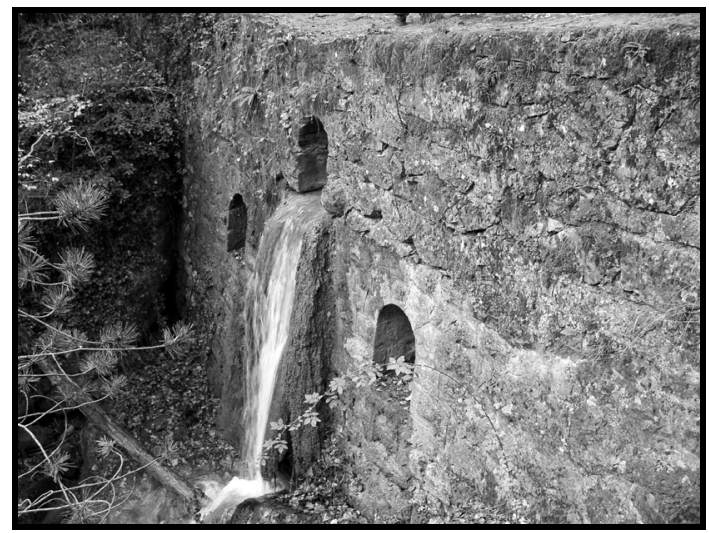

Figure 8: Check dam in 2005.

\section{The watershed}

The values for the main parameters of "los Meses" torrent basin are as follows:

Table 1: $\quad$ Main characteristics of the basin.

\begin{tabular}{|l|l|}
\hline Parameter & Value \\
\hline Area & $163.55($ ha. $)$ \\
\hline Perimeter & $6,402(\mathrm{~km})$. \\
\hline Length & $1.98(\mathrm{~km})$. \\
\hline Average height & $1,500(\mathrm{~m})$. \\
\hline Average gradient & $52.75 \%$ \\
\hline Compactness Índex & 1.41 \\
\hline
\end{tabular}

Geologically it is possible to distinguish a low area (the lower reach) of limestone and dolomite with high infiltration, and a high area (middle and upper reaches) of flysch, with clay and loam, quite impermeable. The large materials present in the channel come from the moraine that bounds the torrent basin, and the small ones from flysch. The works have transformed the longitudinal profile of the riverbed. The channel of the riverbed has been practically reshaped into a succession of waterfalls, in a large stepped channelling.

There is no doubt, but that the merit of this restoration was to reach a dense forest mass in the mountain sides, product of the reforestation programmes. A close forest of P.sylvestris was created in the lower and middle areas, with a dense understory and high botanical diversity, dominated mainly by Buxus sempervivens, Corylus avellana, Crataegus monogyna, and Lonicera xylosteum (figure 9). 
The high part of the watershed is occupied by pine stand of P. uncinata, with less understory, and interrupted by patches of dense high mountain grasses. Laburnum anagyroides is also very abundant throughout the basin and so is Alnus glutinosa, especially along the riverbed. In some areas, numerous examples of Acer platanoides, Abies alba, Sorbus aucuparia or Sorbus aria can also be seen.

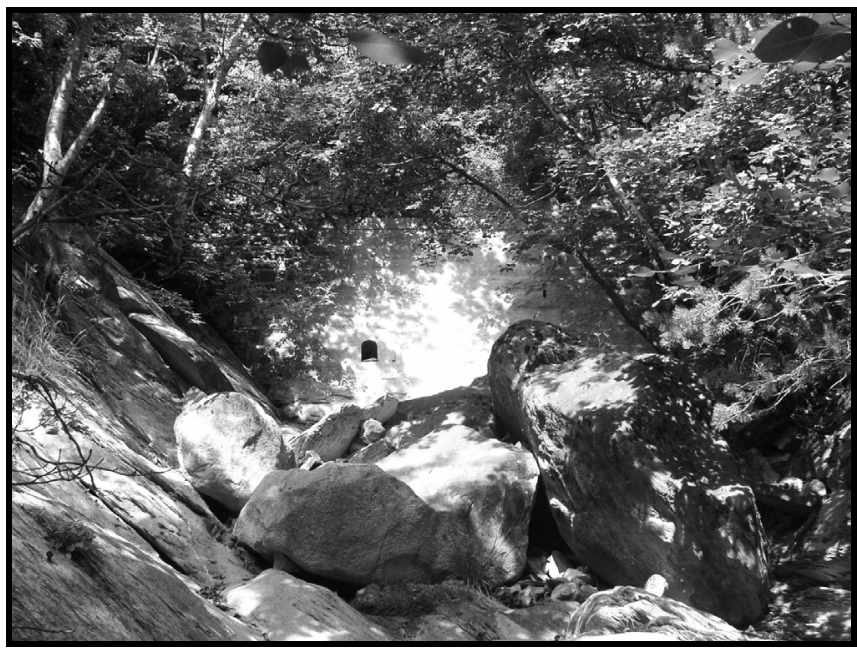

Figure 9: Botanical diversity in the shares (November 2004).

\section{Torrential hydraulics}

Due to the abruptness of the passage, to the continuous waterfalls and abrupt section changes, it has not been possible to model the behaviour of the waters by means of any computer programme. The liquid and solid flows have been calculated, and an intense analysis has been made of the indicators of the hydraulic behaviour of the torrent on site.

For the calculation of the liquid flows, the most common methodology used in Spain for small watersheds has been applied, as proposed by Témez [11] as an application of the so called Rational Method.

$$
q_{p}=K \cdot \frac{C \cdot I \cdot A}{3,6}
$$

where,

$\mathrm{q}_{\mathrm{p}}$, is the generated flow tip, associated to a period of return $\left(\mathrm{m}^{3} / \mathrm{s}\right)$.

$\mathrm{I}$, is the maximum intensity of the precipitation in the concentration time $(\mathrm{mm} / \mathrm{h})$.

A, is the catchment area of the basin $\left(\mathrm{km}^{2}\right)$.

$\mathrm{C}$, is the nondimensional runoff water coefficient,

$\mathrm{K}$ coefficient of uniformity, calculated based on the concentration time. 
The intensity in the time of the concentration has been calculated in two ways. The first one has been following the procedure proposed by the Spanish Regulation of Highways 5.2-I.C, which adopts the following formula:

$$
I=\frac{P_{d}}{24} \cdot\left(\frac{I_{1}}{I_{d}}\right)^{\frac{28^{0,1}-D^{0,1}}{28^{0,1}-1}}
$$

where,

$\mathrm{I}$, is the precipitation intensity associated to a period D (minutes/hour).

$\mathrm{P}_{\mathrm{d}}$, is daily precipitation to be transformed into intensity in a period $\mathrm{D}$.

$\mathrm{D}$, is the period for which the intensity is to be calculated.

$\mathrm{I}_{1} / \mathrm{I}_{\mathrm{d}}$, is a regionalised parameter which, according to the map proposed by Témez, is worth 10 in Canfranc.

The other procedure is the one proposed by Salas [10], in a revision of the formula, which offered new more detailed maps of I

$$
I=K^{\frac{24^{a}-D^{a}}{24^{a}-1}}
$$

where, $\mathrm{K}$ is the regionalised parameter of the high point, which in the new map gives value 6 for Canfranc, and a is a new regionalised parameter which gives value, $\mathrm{a}=0,075$, in Canfranc.

The curve number, for the calculation of the runoff water threshold and with it the runoff water coefficient, was fixed at 75 for the hydrological condition II, and 87,5 for condition III.

The concentration time was calculated by means of the formulas proposed by Kirpich, Témez, and Giandiotti (table 2). On the other hand, in accordance with the slope, length, and ruggedness of the reaches of the course, the journey time of the water along the course was estimated, applying Manning, to which an estimate of the runoff time from the hillsides was added, based on nomograms. The result was more or less an empirical estimate of the actual concentration time of the corrected basin, which more or less is coincident with the one obtained by means of Giandiotti's formula (it is a little higher).

Table 2: $\quad$ Concentration time according to the most well known formulas.

\begin{tabular}{|l|l|}
\hline Formula used & Concentration time \\
\hline Kirpich & 0.176 hours \\
\hline Giandiotti & 0.35 hours \\
\hline Témez & 0.66 hours \\
\hline
\end{tabular}

The maximum precipitations associated to different return periods were estimated based on the Gumbel distribution functions for maximums and on SQRT- ET $_{\text {MAX }}$ (table 3). The values for the highest return periods (from 500 years) are superior for the latter; the rest are very similar. 
For the solid flows, the first task was to determine the threshold flow for the beginning of the movement, applying a package of formulas based on the critical tension of sediment (Schoklitsch, Shields, Miller, Meyer-Peter). Other formulae were used which propose a direct estimate of the critical flow, always according to the slope, the hydraulic radius, and the size of the materials (Bathurst, Rickenmann, Wittaker and Jaeggi, Lafort). However, none of the formulas offered results coherent with what was observed on site, since the critical flows obtained were very small to move large size materials. In fact, on some visits to the ravine flows higher to those obtained were observed, and the water flowing was clean. This is because the formulas used were obtained by means of laboratory experiments for slopes that are less steep that the ones found on site, and above all, for materials smaller in size in one or two orders of magnitude.

Nevertheless, as a trial, the solid flow in three representative sections was calculated, one for each reach, using the Smart and Jaeggi formula, considered the most appropriate formula for enclosed beds and those with a steep gradient in several experiments.

It was applied for all three sections, according to flows of T100 and T500 years, and for two cases: condition of extreme adversity (CT of Kirpich, NCIII, and flow obtained by the classic procedure) and for normal conditions (CT of Giandiotti, NCII, flow obtained according to Salas). The results of flows obtained were as follows:

Table 3: $\quad$ Values of precipitation for various return periods.

\begin{tabular}{|l|l|l|}
\hline $\begin{array}{l}\text { Return Period } \\
\text { (years) }\end{array}$ & $\begin{array}{l}\text { Gumbel } \\
(\mathrm{mm})\end{array}$ & $\begin{array}{l}\text { SQRT- } \\
\mathrm{ET}_{\text {MAX }}(\mathrm{mm})\end{array}$ \\
\hline 50 & 148.40 & 152.82 \\
\hline 100 & 161.28 & 172.09 \\
\hline 500 & 191.04 & 217.38 \\
\hline
\end{tabular}

Table 4: $\quad$ Following classic procedure, with NCII.

\begin{tabular}{|l|r|c|c|c|c|c|}
\hline \multirow{2}{*}{$\begin{array}{l}\text { T } \\
\text { (years) }\end{array}$} & \multicolumn{3}{|c|}{ Gumbell } & \multicolumn{3}{c|}{ SQRT-ET } \\
\cline { 2 - 7 } & $\mathrm{tc}=0,176$ & $\mathrm{tc}=0,35$ & $\mathrm{tc}=0,66$ & $\mathrm{tc}=0,176$ & $\mathrm{tc}=0,35$ & $\mathrm{tc}=0,66$ \\
\hline 50 & 45,2 & 32,3 & 23,4 & 47,3 & 33,7 & 24,5 \\
\hline 100 & 51,3 & 36,6 & 26,5 & 55,9 & 39,9 & 28,9 \\
\hline 500 & 65,5 & 46,7 & 33,9 & 78,4 & 55,9 & 40,5 \\
\hline
\end{tabular}

Table 5: $\quad$ Following classic procedure, with NCIII.

\begin{tabular}{|l|r|c|c|r|r|r|}
\hline \multirow{2}{*}{ T } & \multicolumn{3}{|c|}{ Gumbell } & \multicolumn{3}{c|}{ SQRT-ET } \\
\cline { 2 - 7 } & $\mathrm{tc}=0,176$ & $\mathrm{tc}=0,35$ & $\mathrm{tc}=0,66$ & $\mathrm{tc}=0,176$ & $\mathrm{tc}=0,35$ & $\mathrm{tc}=0,66$ \\
\hline 50 & 61,2 & 43,7 & 31,7 & 63,5 & 45,3 & 32,8 \\
\hline 100 & 67,7 & 48,3 & 35,0 & 72,7 & 51,8 & 37,6 \\
\hline 500 & 82,7 & 59,0 & 42,8 & 96,0 & 68,5 & 49,6 \\
\hline
\end{tabular}


Table 6: $\quad$ Following Salas procedure, with NCII.

\begin{tabular}{|l|r|c|r|r|r|r|}
\hline \multirow{2}{*}{$\begin{array}{l}\text { T } \\
\text { years })\end{array}$} & \multicolumn{3}{|c|}{ Gumbell } & \multicolumn{3}{c|}{ SQRT-ET } \\
\cline { 2 - 7 } & $\mathrm{tc}=0,176$ & $\mathrm{tc}=0,35$ & $\mathrm{tc}=0,66$ & $\mathrm{tc}=0,176$ & $\mathrm{tc}=0,35$ & $\mathrm{tc}=0,66$ \\
\hline 50 & 24,2 & 17,9 & 13,6 & 25,3 & 18,8 & 14,2 \\
\hline 100 & 27,4 & 20,3 & 15,4 & 30,0 & 22,2 & 19,5 \\
\hline 500 & 35,0 & 26,0 & 19,7 & 41,9 & 31,1 & 23,5 \\
\hline
\end{tabular}

Table 7: $\quad$ Following Salas procedure, with NCIII.

\begin{tabular}{|l|r|c|r|r|r|r|}
\hline \multirow{2}{*}{$\begin{array}{l}\text { T } \\
\text { years })\end{array}$} & \multicolumn{3}{|c|}{ Gumbell } & \multicolumn{3}{c|}{ SQRT-ET } \\
\cline { 2 - 7 } & $\mathrm{tc}=0,176$ & $\mathrm{tc}=0,35$ & $\mathrm{tc}=0,66$ & $\mathrm{tc}=0,176$ & $\mathrm{tc}=0,35$ & $\mathrm{tc}=0,66$ \\
\hline 50 & 32,7 & 24,3 & 18,4 & 33,9 & 25,2 & 19,1 \\
\hline 100 & 36,2 & 26,9 & 20,3 & 38,8 & 28,8 & 21,8 \\
\hline 500 & 44,2 & 32,8 & 24,8 & 51,3 & 38,1 & 28,8 \\
\hline
\end{tabular}

Table 8: $\quad$ Flows.

\begin{tabular}{|c|c|c|}
\hline Section & $\begin{array}{l}\text { tc }=0,176 ; \quad I_{1} / I_{d}=10 ; \\
N_{\text {III }}\end{array}$ & $\mathrm{tc}=0,35 ; \mathrm{K}=7 ; \mathrm{NC}_{\mathrm{II}}$ \\
\hline Right branch & $\begin{array}{l}\mathrm{T}(100): 3,57 \mathrm{~m}^{3} / \mathrm{s} \\
\mathrm{T}(500): 4,66 \mathrm{~m}^{3} / \mathrm{s}\end{array}$ & $\begin{array}{l}\mathrm{T}(100): 0,95 \mathrm{~m}^{3} / \mathrm{s} \\
\mathrm{T}(500): 1,58 \mathrm{~m}^{3} / \mathrm{s}\end{array}$ \\
\hline Up the road & $\begin{array}{l}\mathrm{T}(100): 14,16 \mathrm{~m}^{3} / \mathrm{s} \\
\mathrm{T}(500): 18,51 \mathrm{~m}^{3} / \mathrm{s}\end{array}$ & $\begin{array}{l}\mathrm{T}(100): 4,43 \mathrm{~m}^{3} / \mathrm{s} \\
\mathrm{T}(500): 5,99 \mathrm{~m}^{3} / \mathrm{s}\end{array}$ \\
\hline End of catchment & $\begin{array}{l}\mathrm{T}(100): 2,70 \mathrm{~m}^{3} / \mathrm{s} \\
\mathrm{T}(500): 3,57 \mathrm{~m}^{3} / \mathrm{s}\end{array}$ & $\begin{array}{l}\mathrm{T}(100): 0,81 \mathrm{~m}^{3} / \mathrm{s} \\
\mathrm{T}(500): 1,13 \mathrm{~m}^{3} / \mathrm{s}\end{array}$ \\
\hline
\end{tabular}

\section{Conclusions}

The liquid flows obtained for average conditions according to the procedure proposed by De Salas [10] are low and coherent with what is observed on site. The succession of check-dams, perfectly integrated into the profile of the bed and the landscape, not only causes a compensation in the slope, but it also makes each dike section get wider, and also acts like an area of lamination on the avenue. Because of that, and because of the large size of the materials and the soil and moss that grow on them, the values of the solid flows do not seem very credible. It is very unlikely for these materials to be moved, but even in case they were, it would be less probable that they could be found in the outlet of the basin. Numerous structures, as well as profuse vegetation, would stop them. It is easy to observe that in some check-dams the flow digresses over deposited materials, like in a small alluvial cone.

It is also easy to observe the incision of the bed in the area of the diversion wall built by the local population. The water circulates on an incision of $4 \mathrm{~m}$ above the crown of the wall. According to articles of the period, the materials reached there when the stream control works began, and in 1925, the water had already impacted $2 \mathrm{~m}$. That would mean that in 80 years it has only impacted 
another $2 \mathrm{~m}$., which indicates that the water which has been coming down since then has done so without bedload transport of importance, and in little quantity, as the annual incision is small.

Therefore, the conclusion is that 80 year later, the great restoration which was carried out (the combination of reforestation and stream control works) not only keeps the torrent in its inactive state, preventing it from creating problems for the village again, but also maintains the beautiful, purely Pyrenean landscape, in which it is impossible to imagine either the state it was in less than a century ago, or the intelligent engineering needed to achieve it.

\section{References}

[1] Azpeitia, F., El torrente Los Meses y su corrección hidrológico-forestal. España Forestal, no 95, pp. 46-47. 1924

[2] Azpeitia, F., El torrente Los Meses y su corrección hidrológico-forestal (Conclusión. España Forestal, nº 97, pp. 69-72. 1924

[3] Chauvelier, F., La repoblación forestal en la provincia de Huesca y sus impactos geográficos. Instituto de Estudios Altoaragoneses, Huesca. 1990

[4] Deymier, C., Tacnet, J.M. \& Mathys, N., Equipaments pour l'eau et l'environnenment. Études de Ceagref, Série Équipaments pour l'eau et l'environnement $\mathrm{n}^{\circ} 18$. Grenoble. 1995

[5] Dvorak, J. \& Novack, L. (eds.), Soil Conservation and Silviculture. Development in Soil Science 23. Elsevier Science Publishers. Praga.1994

[6] Ergenzinger, P. \& Schmidt, K.H. (eds.),. Dynamics and Geomorphology of Mountain Rivers. Springer-Verlag. Berlin. 1994

[7] García Nájera, J.M. \& Ayerbe, J.M., Principios de hidráulica torrencial: su aplicación a la corrección de torrentes. Corrección de aludes. Ministerio de Agricultura. Dirección General de Montes, Caza y Pesca Fluvial. Instituto forestal de Investigaciones y Experiencias. Madrid. 1962

[8] García, J.L.,. Manual de cálculo de diques de corrección torrencial. Servicio de publicaciones de la E.T.S.I Montes. Madrid. 2001

[9] Meunier, M.,. Elements d'hydraulique torrententialle. Études de Cemagref, Série Montagne, nº 1. Grenoble. 1991

[10] Salas, L. de, Regionalización de leyes IDF para el uso de modelos hidrometereológicos de estimaciones de caudales. Universidad Politécnica de Madrid Doctoral Thesis. 2004.

[11] Témez, J.R. Cálculo de caudales hidrometeorológicos en pequeñas cuencas hidrográficas. Ministerio de Obras Públicas. 1978 